\title{
再生式熱交換器とその設計指針
}

\author{
濱口 $\quad$ 和洋 $^{* 1}$
}

\section{Regenerative Heat Exchanger and Its Design Approach}

\author{
Kazuhiro HAMAGUCHI ${ }^{* 1}$
}

\begin{abstract}
Synopsis: The regenerator is an indispensable regenerative heat exchanger in Stirling cycle machines, G-M cryocoolers and pulse tube cryocoolers. Its existence is a key factor in enabling these machines to have the highest thermal efficiency and coefficient of performance. A regenerator is composed of a matrix and housing. The matrices are often made of stacks of fine wire mesh screens. However, an optimum balance between flow loss and heat transfer characteristics is required. In this report, based on the theoretical studies of thermal behavior in wire elements and matrices, relationships between design factors are obtained. An approach for designing regenerator used in Stirling cryocoolers is presented.
\end{abstract}

Keywords: temperature ratio, temperature efficiency, flow loss, reheat loss, indicated COP

(Some figures in this article may appear in colour only in the electronic version)

\section{1. はじめに}

スターリングエンジン，並びに GM 冷凍機，スターリ ング冷凍機に代表される蓄冷器方式極低温冷凍機の性能は 再生式熱交換器（蓄熱再生熱交換器）の性能に大きく影響 される。この熱交換器は，スターリングエンジンでは再生 器, 極低温冷凍機では蓄冷器そして熱音響機器ではスタッ クと呼ばれ，これらの熱機器には必要不可欠である。本稿 では蓄冷器を対象として，その基本構成と役割，設計に際 して必要な要求項目，蓄冷材であるマトリックスの種類と 特性，各種損失の評価法と総合的な評価法を紹介し，蓄冷 器の設計指針を述べる。

\section{2. 再生式熱交換器}

\section{1 基本構成と役割}

Fig. 1 にスターリングサイクル機器における再生式熱交 換器（再生器あるいは蓄冷器）のクーラ・放熱器とヒー タ・吸熱器との位置関係を示す。再生式熱交換器は，八ウ ジングの中にマトリックスと呼ばれる蓄熱材あるいは蓄冷 材が充填された単純な構成である。そのマトリックスは, 作動ガスと直接接触することにより，作動ガスとの間で熱 交換を行い，蓄熱そして放熱する直接接触式の蓄熱再生式

Received August 10, 2016

${ }^{* 1}$ 明星大学理工学部

干191-8506 東京都日野市程久保 2-1-1

Meisei University, 2-1-1 Hodokubo, Hino, Tokyo 191-8506, Japan

E-mail: hamaguch@me.meisei-u.ac.jp

DOI : $10.2221 /$ jcsj.51.385
熱交換器である。

本稿では，蓄冷器を取り上げ，Fig. 1 並びに Fig. 2 を用 いてその役割を述べる。蓄冷器は, 低温部の熱の吸い込み 場である吸熱器から流入した作動ガスのエントロピーを放 熱器から周縁環境に放出する際のエントロピーの流路にな る。その働きは, Fig. 2 に示寸圧縮空間から放熱器を経て

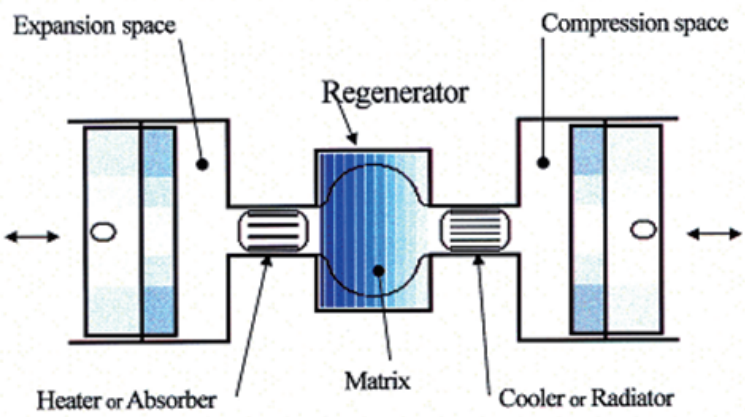

Fig. 1 Stirling cycle machine.

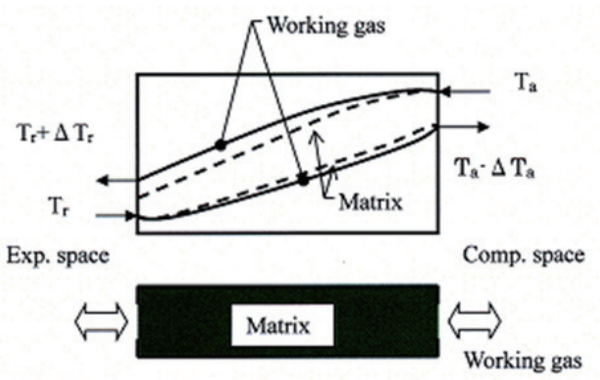

Fig. 2 Temperature distribution in regenerator 
蓄冷器に流入する常温の作動ガスは，その保有する熱量を マトリックスに蓄熱させ, 低温になって膨張空間に流出し 吸熱する。一方，吸熱した作動ガスは膨張空間から蓄冷器 に流入し, マトリックスより受熱し, 放熱器で周縁環境に 放熱しながら圧縮空間に流出する。蓄冷器で交換される熱 量は, 冷凍能力と比較すると大きく, 蓄冷器の役割は非常 に重要になる。

\section{2 蓄冷器の出入口流路の影響 ${ }^{1)}$}

Fig. 1 に示すように, 蓄冷器は吸熱器及び放熱器の間に 位置しているため, その出入口において狭窄流路が存在す ることが多い。そのため, Fig. 3 に示すようにマトリック ス中の作動ガスの流れはその出入口付近において拡大・縮 小流れを伴い, 不均一な流速分布（非一様流れ）を誘起 し，過大な圧力損失と伝熱性能低下の原因となる。この場 合, 流路の拡大縮小を伴うマトリックス中の流れを等価流 路断面積 ${ }^{2}$ により評価し，その流れにより圧力損失や伝熱 性能を評価する必要がある。

非一様流れの解消には蓄冷器出入口にテーパ流路や間隙 流路を設けることが有効であり，間隙流路及びテーパ流路 の設置による非一様流れの解消効果は大きく, 特に同一無 効容積の場合, Fig. 4 に示すテーパ流路の効果がさらに大 きい。なお，間隙及びテーパ流路の効果は，縮小流れ場よ りも拡大流れ場において大きく, テーパ流路の効果はマト リックスの流動抵抗にそれほど依存しないが，間隙流路の 場合は依存することが分かっている。実際, 蓄冷器出入口 形状は, 放熱器側の常温端において, 冷凍性能に影響を及 ぼすことが確認されている ${ }^{3)}$.

\section{3 蓄冷器への要求項目}

蓄冷器には次の性能が要求される。

a) 作動ガスとの蓄熱再生作用が十分行われ, 蓄熱再生熱 交換損失（再熱損失）が小さい。すなわち, 次の条件を 満足させる必要がある。

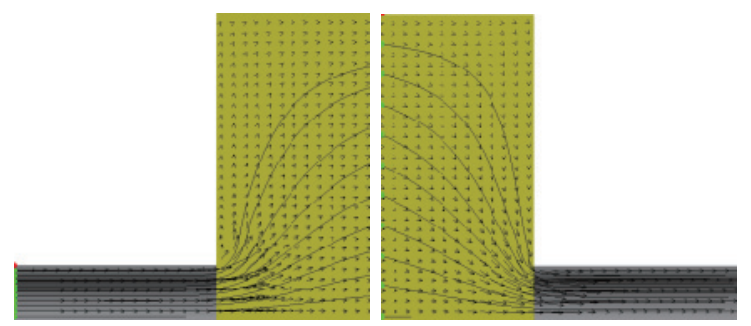

Fig. 3 Effects of normal flow passage at regenerator.

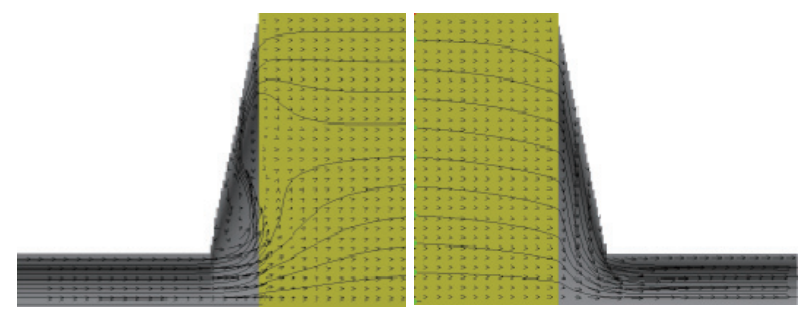

Fig. 4 Effects of tapered flow passage at regenerator.
・通過する作動ガスの熱容量と比較して十分大きい熱容量 を有する。

・作動ガスとの間での熱伝達率及び伝熱表面積が十分大き い。

b) 作動ガスの流れ方向への熱伝導が小さい。

c) 通過する作動ガスの圧力損失が小さい。

d) 無効容積（蓄熱再生に寄与しない空間）の減少を図 る。

\section{4 マトリックスの種類と特性}

マトリックスには, 伝熱性能が高く, 流動抵抗の小さい ことのほか, 流れ方向への熱伝導の低いことが要求され る。このような材料として, 密着積層した 200〜 400 メッ シュ程度（線径 $\phi 0.05 \sim 0.03 \mathrm{~mm}$ 程度）の金網, 密接に詰 め込まれた微小球体粒子（ペブル）などが使用される。マ トリックス材には次の性能が要求される。

a) 作動ガスの温度レベルに依存した体積比熱を有する。

b) 単位体積当たりの伝熱表面積（比表面積）が十分大き い。

c) 開口比（=マトリックス中の流路面積／前断面積）が 比較的大きい。

d) 網状並びに球形（ペブル）への加工が容易である。

e) 剥離, 破損しにくい。

これらの項目の中で，b)と c)については，それほどの問 題にならないが，a)とそれに付随した d) と e)に問題が残 る。特に作動ガスに使用されるへリウムの定圧比熱 $C_{\mathrm{p}}$ の 温度依存性は, 圧力レベル $1 \mathrm{MPa}$ あいは $2 \mathrm{MPa}$ におけ る温度領域 10〜 $20 \mathrm{~K}$ にて大きい。一方, 銅と鉛の比熱 は, 温度の低下に伴い急激に低下寸る。実際, $4.2 \mathrm{~K}$ にお ける鉛の比熱はほぼ 0 である。すなおち，70 K レベルの 冷凍機までは, 銅, 燐青銅, ステンレス鋼などの通常の金 属材料を用いた金網や綿状繊維，10 K レベルまでは鉛の ペブルが使用される。しかし，10 K 以下になると金属材 料の使用は困難になる。この解決には, 磁性材料が必要に なる。この材料には, Gd, Dy, Ho, Er などの重希土類元 素の合金や化合物があげられる。しかし, 磁性材料は柔ら かすぎるため, 網状に編み上げるあるいは一様な球体など 利用しやすい形状に加工することが難しく，材料自体の信 頼性に影響を及ぼす破損も生じやすい。

\section{3. マトリックスの基本特性}

$70 \mathrm{~K}$ レベルのマトリックスとしてよく使用される積層 金網の流動及び伝熱特性に関する評価について述べる。通 常, 積層金網を使用する場合, その積層方法には, Fig. 5(a)に示す作動ガスの流れに垂直に積層する垂直積層ある いは Fig. 5(b)に示す作動ガスの流れに平行に積層する平行 積層が考えられる。しかし，一般的には，Fig. 5(a)に示す 垂直積層が使用されている。ここでは, 積層金網の基本特 性評価に必要な整理式を述べるとともに積層方法の基本特 


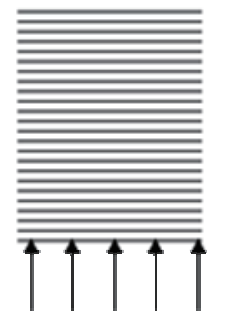

(a) Vertical stack

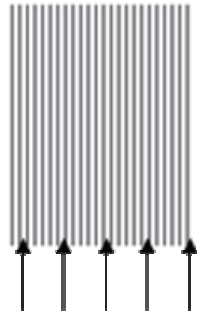

(b) Parallel stack
Fig. 5 Stacking method of wire gauzes.

性への影響, さらには垂直積層の基本特性評価式を紹介す る。

(1) 幾何学的形状值

各特性の評価に用いる積層金網の幾何学的形状值は，比 表面積 $\sigma\left(\mathrm{mm}^{2} / \mathrm{mm}^{3}\right)$, 水力直径 $d_{\mathrm{h}}(\mathrm{mm})$ そして空隙率 $\phi$ で ある。

a) 比表面積

比表面積 $\sigma$ は，積層金網の単位体積当たりの伝熱表面積 を表し，次式で定義される。

$$
\sigma=\frac{4(1-\phi)}{d_{\mathrm{m}}}
$$

ここで， $d_{\mathrm{m}}$ は金網の線径 $(\mathrm{mm})$ である。

b) 水力直径

水力直径 $d_{\mathrm{h}}$ は次のように定義される。

$$
\begin{aligned}
d_{\mathrm{h}} & =4 \times \text { 流路断面積 } / \text { 濡れぶち長さ } \\
& =4 \times \text { 空隙率 } / \text { 比表面積 }=\frac{4 \phi}{\sigma}
\end{aligned}
$$

c) 空隙率

空隙率 $\phi$ は，使用される積層金網の質量を測定して算出 するのが現実的である。

(2) 圧力損失の整理式

積層金網の圧力損失 $\Delta P(\mathrm{~Pa})$ は摩擦係数 $f$ に換算され, レイノルズ数 Re の関数として表す。摩擦係数 $f$, レイノ ルズ数 Re そして流速 $u$ は次式で定義される。

$$
\begin{aligned}
& f=d_{\mathrm{h}} \frac{\Delta P}{l r} / \frac{1}{2} \rho u^{2} \\
& R e=\frac{d_{\mathrm{h}} u}{v} \\
& u=\frac{u_{0}}{\phi}
\end{aligned}
$$

ここで, $l r$ はマトリックス長さ $(\mathrm{m}), \quad \rho$ と $v$ は作動ガスの 密度 $\left(\mathrm{kg} / \mathrm{m}^{3}\right)$ と動粘度 $\left(\mathrm{m}^{2} / \mathrm{s}\right)$ そして $u$ はマトリックス全断面 での流速 $u_{0}$ を空隙率 $\phi$ で除したマトリックス中の流速 $(\mathrm{m} / \mathrm{s})$ を表す。

(3) 平均熱伝達率の整理式

積層金網の平均熱伝達率 $\alpha_{\mathrm{m}}\left(\mathrm{W} /\left(\mathrm{m}^{2} \mathrm{~K}\right)\right)$ はヌセルト数 $N u$

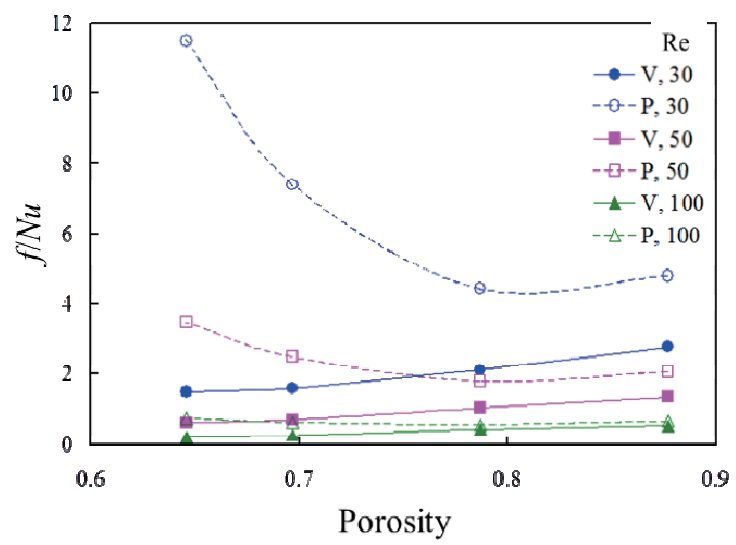

Fig. 6 Effects of stacking method and porosity on balance values of two characteristics.

に換算され，レイノルズ数 Re の関数として表す。ヌ セルト数 $N u$ は次式で定義される。

$$
N u=\frac{d_{\mathrm{h}} \alpha_{\mathrm{m}}}{\lambda_{\mathrm{g}}}
$$

ここで， $\lambda_{\mathrm{g}}$ は作動ガスの熱伝導率 $(\mathrm{W} /(\mathrm{mK}))$ である。

(4) 積層方法の基本特性への影響 ${ }^{4)}$

Fig. 6 には，定常流試験により得られた金網積層方法が 基本特性に及ぼす影響を示す。同図にはレイノルズ数 Re 一定下（30，50，100）での金網の垂直積層体 V と平行積 層体 $\mathrm{P}$ が空隙率と $f / N u$ との関係に及ぼす影響を示す。 $f / N u$ は伝熱性能に対する圧力損失性能の影響を示し, $f / N u$ 值が小さい場合に圧力損失と伝熱性能のバランスの良いこ とを示す。同図によると, 全体的には平行積層の $f / N u$ 值 が垂直積層より劣っている。しかし, レイノルズ数の増加 につれて, 両積層方法の $f / N u$ 值への影響はほぼ同じにな る。また, レイノルズ数の増加は $f / N u$ 值を低下させるこ とにつながり，その影響は平行積層に大きく現れてくる。 空隙率の $f / N u$ 值への影響は平行積層と垂直積層とは異な り, 平行積層では空隙率の増加に伴い $f / N u$ 值が減少そし て垂直積層では空隙率の減少と共に $f / N u$ 值が減少してい る。これは, 空隙率の大きい範囲では平行積層の圧力損失 は低いが空隙率の減少につれて過大になることを示す。垂 直積層では，その圧力損失は大きいものの伝熱性能の優れ ることを示し, 空隙率低下による伝熱性能の向上傾向が現 れている。その結果, 全体的には垂直積層体の基本特性が 優れることが分かったので，ここでは垂直積層体の基本特 性評価式を述べる。

(5) 垂直積層金網の基本特性評価式

マトリックス材によく使用される垂直積層金網の流動及 び伝熱特性に関する評価式の一例として非定常往復流実験 により得られた田中の実験式 5)を示す。流動特性について は式(7)の摩擦係数 $f$ そして伝熱特性については式(8)のヌ セルト数とレイノルズ数 Re との関係で表されている。 


$$
\begin{aligned}
& f=\frac{175}{R e}+1.60 \\
& N u=0.33 R e^{0.67}
\end{aligned}
$$

式(7)，(8)並びに整理式(3)，(4)，(6)の使用により，積層 金網を用いた蓄冷器の圧力損失及び伝熱性能の評価が可能 になる。ところで，これらの評価式の導出には種々の方 法 ${ }^{6}$ があり，利用条件により他の整理式，実験式の使用も 可能である。

(6) 熱伝導率の評価式 ${ }^{7)}$

垂直積層金網における積層方向の有効熱伝導率 $\lambda_{\mathrm{e}}(\mathrm{W} /$ $(\mathrm{mK}))$ の推算式が定常加熱実験より次式のように導かれて いる。

$$
\lambda_{\mathrm{e}}=A \lambda_{\mathrm{g}}+\frac{(1-A) \ln \left\{1+2 \Psi\left(\frac{\lambda_{\mathrm{s}}}{\lambda_{\mathrm{g}}}-1\right)\right\}}{2 \Psi\left(\frac{1}{\lambda_{\mathrm{g}}}-\frac{1}{\lambda_{\mathrm{s}}}\right)}
$$

ここで， $\lambda_{\mathrm{s}}$ と $\lambda_{\mathrm{g}}$ は素材と作動ガスの熱伝導率 $(\mathrm{W} /(\mathrm{mK}))$, 係数 $A$ と $\Psi$ は次式で定義される。

$$
A=\left\{1-\frac{4(1-\phi)}{\pi}\right\}^{2} \quad, \quad \Psi=\frac{\phi-A}{1-A}
$$

\section{4. マトリックス材の形状寸法}

\section{1 金網素線径の影響 ${ }^{8)}$}

マトリックスとして金網を使用する場合，蓄熱部が素線 内であり，その素線径が蓄冷器の伝熱性能に大きく影響す る。その影響を簡略的に示したのが Fig. 7 である。

同図中，上図の素線円形断面内の矢印は熱の浸透深さ， 院影部は有効な蓄熱部，白抜き部は無効な蓄熱部を示す。 また，下図には素線（線径 $d_{\mathrm{m}}$ ) に流入する高温の作動ガス (無次元温度 $T_{\mathrm{f} \text { in }}^{*}$ ) が素線内に吸熱され，低温の作動ガス $\left(T_{\mathrm{f} \text { out }}^{*}\right)$ となり流出する様子を示している。ここで, Fig. 7(b)を最適な素線とすると, 素線径の小さい Fig. 7(a)の場 合，作動ガス温度が十分低下しないため積層枚数を増加さ

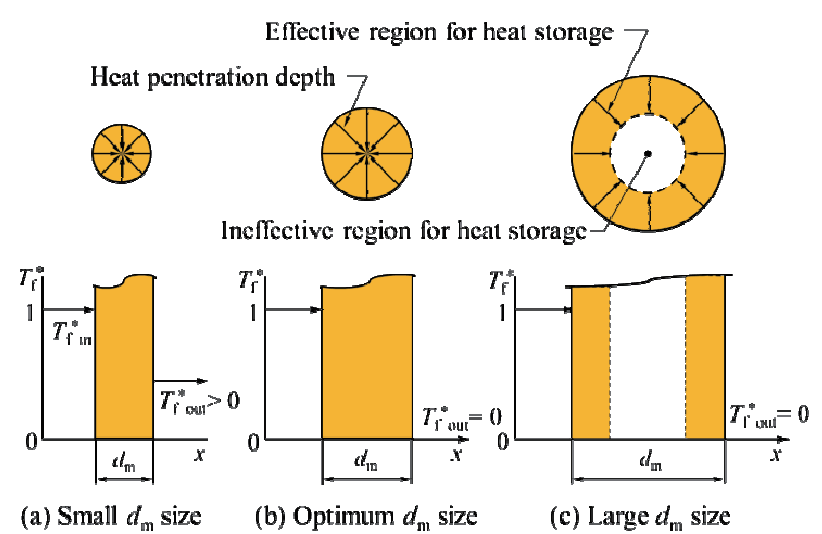

Fig. 7 Heat storage in a wire element.
せる必要があり，その結果，流動抵抗が過大になる。線径 の大きい Fig. 7(c)の場合, 素線内に蓄熱に関与しない無効 蓄熱部が生じ, 設計の際に十分な熱容量を有するように積 層枚数を選んだとしても，実際に有効な熱容量は不足す る。したがって, Fig. 7(b)のような使用条件にあった線径 を有する金網の選択が不可欠である。

最適な線径を選ぶために用意されているのが素線中心温 度比 $T r$ をパラメータとしたビオー数 $B i$ とフーリエ数 Fo と の関係を表す Fig. 8 である。同図は，素線を軸対称二次元 熱伝導問題として解析された結果である ${ }^{8)}$ 。素線中心温度 比 $T r$, ビオー数 $B i$, フーリエ数 $F O$ は, 次のように定義さ れる。

$$
\operatorname{Tr}=\left(\frac{T_{\mathrm{d}}}{T_{\mathrm{fm}}}\right)_{R=0}
$$

ここで， $T_{\mathrm{d}} / T_{\mathrm{fm}}$ は素線表面温度に対する素線温度を示し， $R=0$ は素線中心部を示す。

$$
B i=\frac{\alpha_{\mathrm{m}} d_{\mathrm{m}}}{2 \lambda_{\mathrm{d}}}
$$

ここで， $\alpha_{\mathrm{m}}$ は素線表面の平均熱伝達率 $\left(\mathrm{W} /\left(\mathrm{m}^{2} \mathrm{~K}\right)\right), d_{\mathrm{m}}$ は線 径， $\lambda_{\mathrm{d}}$ は素線の熱伝導率 $(\mathrm{W} /(\mathrm{mK}))$ を示す。

$$
F O=\frac{4 \kappa_{\mathrm{d}} t}{d_{\mathrm{m}}^{2}}
$$

ここで， $\kappa_{\mathrm{d}}$ は素線の温度伝導率 $\left(\mathrm{m}^{2} / \mathrm{s}\right), t$ は往復する作動 ガスの切り替え時間( $\mathrm{s}$ )を示す。

Fig. 8 の利用にあたり, 蓄冷器の使用条件（作動ガスの 平均圧力, 平均流速, 平均時間並びに通過時間）にあった 線径を有する金網を選ぶ場合, まず線径 $d_{\mathrm{m}}$ を設定し, ビ オー数 $B i$ とフーリエ数 $F_{O}$ を算出し, 素線中心温度比 $T r$ を 求める。その際に $T r=1$ 近傍にならない場合, これを繰り 返し， $T r=1$ 近傍となる線径を有する金網を決定する。

\section{2 マトリックスの伝熱特性 ${ }^{9}$}

前項で選んだ線径を有する金網の積層枚数を決定するた め, Fig. 9 のマトリックスから作動ガスへの受熱過程の温 度効率 $\varepsilon$ を単純化した理論解析により調べ, マトリックス

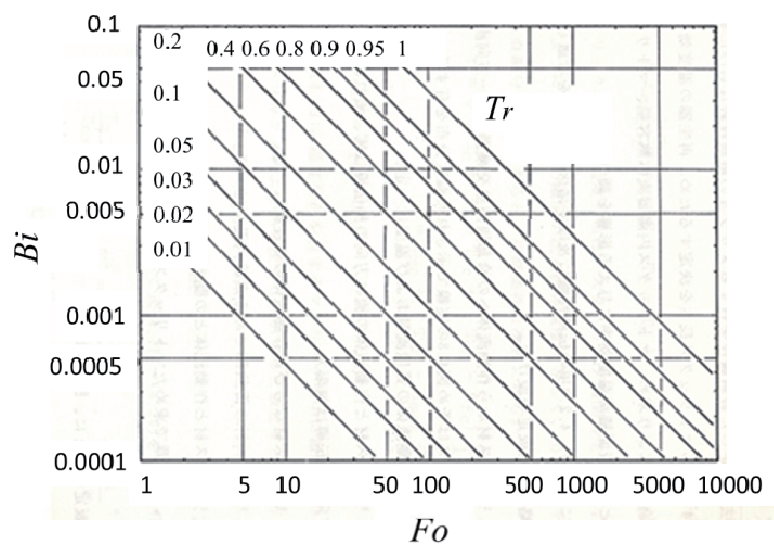

Fig. 8 Relation between $B i$ and $F o$ with temperature ratio $T r$. 
の有するユニット数 $N t u$ および熱容量比 $C r$ との関係で表 したのが Fig. 10 である。図中のユニット数 Ntu, 通過する 作動ガスとの熱容量比 $C r$, 残留ガスとの熱容量比 Crs, 温 度効率 $\varepsilon$ は, 次のように定義される。

$$
N t u=\frac{\alpha_{\mathrm{m}} S}{\dot{m} C_{\mathrm{p}}}
$$

ここで， $\alpha_{\mathrm{m}}$ は式(8)より算出する作動ガスとマトリックス との平均熱伝達率, $S$ は伝熱表面積 $\left(\mathrm{m}^{2}\right), \dot{m}$ は作動ガスの 質量流量 $(\mathrm{kg} / \mathrm{s}), \quad C_{\mathrm{p}}$ は作動ガスの定圧比熱 $(\mathrm{kJ} /(\mathrm{kgK}))$ を示 す。

$$
C r=\frac{M C_{\mathrm{m}}}{\dot{m} C_{\mathrm{p}} t}
$$

ここで, $M$ はマトリックスの質量 $(\mathrm{kg}), C_{\mathrm{m}}$ はマトリックス の比熱 $(\mathrm{kJ} /(\mathrm{kgK})), \quad t$ は作動ガスの切り替え時間( $(\mathrm{s})$ を示す。

$$
C r s=\frac{M C_{\mathrm{m}}}{M_{\mathrm{r}} C_{\mathrm{v}}}
$$

ここで， $M_{\mathrm{r}}$ はマトリックス内に残留するガスの質量 $(\mathrm{kg})$, $C_{\mathrm{v}}$ は作動ガスの定容比熱 $(\mathrm{kJ} /(\mathrm{kgK}))$ である。

$$
\mathcal{E}=\frac{T_{\mathrm{f} x=l r}-T_{\mathrm{f} x=0}}{T_{\mathrm{mh}}-T_{\mathrm{fx}=0}}
$$

ここで， $T_{\mathrm{f} x=l r}$ は低温側より高温側に流れる作動ガスのマト リックス出口温度, $T_{\mathrm{f} x=0}$ はマトリックスに低温側より流入 する作動ガスの温度， $T_{\mathrm{mh}}$ は蓄熱されたマトリックスの高 温端温度である。なお，同式は理想気体に限定される。

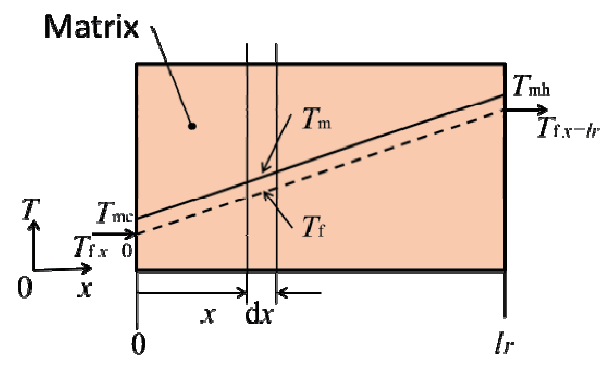

Fig. 9 Control volume of matrix.

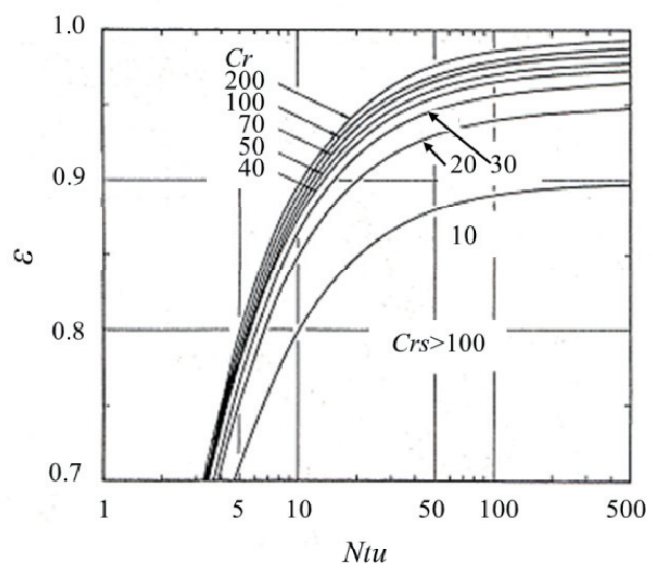

Fig. 10 Temperature efficiency versus $N t u$ with $C r(C r s>100)$.
解析結果 ${ }^{9}$ によると，Crs > 100 では Crs の温度効率 $\varepsilon$ 一 の影響は見られないことから, Fig. 10 より温度効率 $\varepsilon$ $=0.99$ を満足する熱容量比 $C r$ とユニット数 $N t u$ を有する積 層枚数を選ぶと良い。

\section{5. マトリックスの各種損失と総合評価}

蓄冷器性能は, 再熱損失並びに熱伝導損失を十分に減少 させるとともに圧力損失並びに無効容積の低減を図ること により，その最適化が可能である。

各損失量の算出法を次に述べる。ただし, 蓄冷器出入口 に狭窄流路を有する場合, マトリックス中の流速は, 流路 の拡大縮小を考慮した評価 ${ }^{2}$ を行う必要がある。

\section{1 圧力損失}

蓄冷器を作動ガスが流動することにより生じる圧力損失 は, 膨張空間の圧力振幅を小さくし，その仕事すなわち冷 凍能力を低下させる。その損失量 $W_{\mathrm{p}}(\mathrm{W})$ は次式により求 めることができる。

$$
W_{\mathrm{p}}=\frac{\dot{m}}{\rho} \Delta P
$$

ここで， $\dot{m}$ は作動ガスの質量流量， $\Delta P$ は圧力損失， $\rho$ は作動ガスの密度である。

圧力損失 $\Delta P$ は，マトリックスの摩擦係数 $f$ に関寸る実 験式(7)を用いて算出する。

\section{2 再熱損失}

再熱損失 $Q_{\mathrm{r}}(\mathrm{W})$ とは, 作動ガスが常温の圧縮空間から蓄 冷器に流入し, その保有する熱量をマトリックスとの間で 十分に熱交換そして所要の低温が達成できずに，膨張空間 に流出することにより生じる熱損失である。Fig. 2 に示す ように室温 $T_{\mathrm{a}}$ の作動ガスが蓄冷器に流入し, $T_{\mathrm{r}}+\Delta T_{\mathrm{r}}$ の温 度で蓄冷器より流出して低温発生箇所である膨張空間に入 る。また，これとは逆に低温 $T_{\mathrm{r}}$ の作動ガスが蓄冷器に流入 し, $T_{\mathrm{a}}-\Delta T_{\mathrm{a}}$ の温度で蓄冷器より流出して圧縮空間に入る とする。このとき, 冷凍機は冷凍能力の一部を利用して $\Delta T_{\mathrm{r}}$ 分の作動ガス温度を低下させねばならない。この場合 に生じる熱損失すなわち再熱損失 $Q_{\mathrm{r}}$ は次式により表せる。

$$
Q_{\mathrm{r}}=\dot{m} C_{\mathrm{p}} \Delta T_{\mathrm{r}}
$$

ただし， $\dot{m}$ は作動ガスの質量流量， $C_{\mathrm{p}}$ は作動ガスの定圧 比熱である。

冷凍機の性能は，式(18)で算出される損失分だけ低下す ることになる。 $\Delta T_{\mathrm{r}}$ の温度上昇分は, 蓄冷器の非効率性に より発生する。すなわち, 蓄冷器の非効率 $(1-\varepsilon)$ が蓄冷器 の熱的性能の評価に利用される。この非効率は, 蓄冷器で 交換可能な最大熱量 $Q_{\max }$ を用いて次式で表される。

$$
\begin{gathered}
1-\varepsilon=\frac{Q_{\mathrm{r}}}{Q_{\max }} \\
\text { ここで, } Q_{\max } \text { は次のように表される。 } \\
Q_{\max }=m C_{\mathrm{p}}\left(T_{\mathrm{a}}-T_{\mathrm{r}}\right)
\end{gathered}
$$


すなわち，再熱損失は，非効率が分かれば次式により算出 できる。

$$
Q_{\mathrm{r}}=m C_{\mathrm{p}}\left(T_{\mathrm{a}}-T_{\mathrm{r}}\right)(1-\varepsilon)
$$

非効率の算出には，熱伝達性能のみを考慮した式(22)並 びにマトリックスの熱容量の影響も考慮した式(23)が提案 されている。なお, $C r \gg 0$ 場合, 式(23)は式(22)に近似す る。

$$
\begin{aligned}
& 1-\varepsilon=\frac{2}{N t u+2} \\
& 1-\varepsilon=1-C r \cdot \tanh \left\{\frac{N t u}{C r(N t u+2)}\right\}
\end{aligned}
$$

\section{3 熱伝導損失}

蓄冷器における熱伝導損失は，マトリックス並びにその ハウジングにおける圧縮側から膨張側への熱伝導損失があ る。ここでは，マトリックスでの熱伝導損失 $Q_{c}(\mathrm{~W})$ につい て次式で表す。

$$
Q_{\mathrm{c}}=A_{\mathrm{m}} \lambda_{\mathrm{e}} \frac{T_{\mathrm{a}}-T_{\mathrm{r}}}{L r}
$$

ここで, $A_{\mathrm{m}}$ と $\operatorname{Lr}$ はマトリックスの前断面積 $\left(\mathrm{m}^{2}\right)$ と長さ (m), $T_{\mathrm{a}}$ 及び $T_{\mathrm{r}}$ は常温端及び低温端の作動ガス温度 $\left({ }^{\circ} \mathrm{C}\right)$ そ して $\lambda_{\mathrm{e}}$ はその推算式(9)より算出されるマトリックスの 有効熱伝導率である。

\section{4 図示 COP による総合評価}

スプリット形スターリング冷凍機（77 K, 1 W）のヒート バランス ${ }^{10)}$ が Fig. 11 に示されている。

同図より，スターリングタイプの冷凍機に係る図示成績 係数 $C O P_{\mathrm{i}}$ は次式により定義される。

$$
C O P_{\mathrm{i}}=\frac{\left|W_{\mathrm{e}}\right|-Q_{\mathrm{r}}-Q_{\mathrm{c}}-\Sigma Q_{\mathrm{o}}}{\left|W_{\mathrm{i}}\right|-W_{\mathrm{p}}-\Sigma W_{\mathrm{o}}}
$$

ここで， $W_{\mathrm{e}}$ 及び $W_{\mathrm{i}}$ は損失のない膨張及び図示仕事 $(\mathrm{W})$, $\Sigma Q_{\mathrm{o}}$ 及び $\Sigma W_{\mathrm{o}}$ は蓄冷器における再熱損失 $Q_{\mathrm{r}}$, マトリック スの熱伝導損失 $Q_{\mathrm{c}}$ 並びに圧力損失 $W_{\mathrm{p}}$ を除く各種熱損失 及び各種比可逆仕事の和である。 $\Sigma Q_{\mathrm{o}}$ には八ウジングの

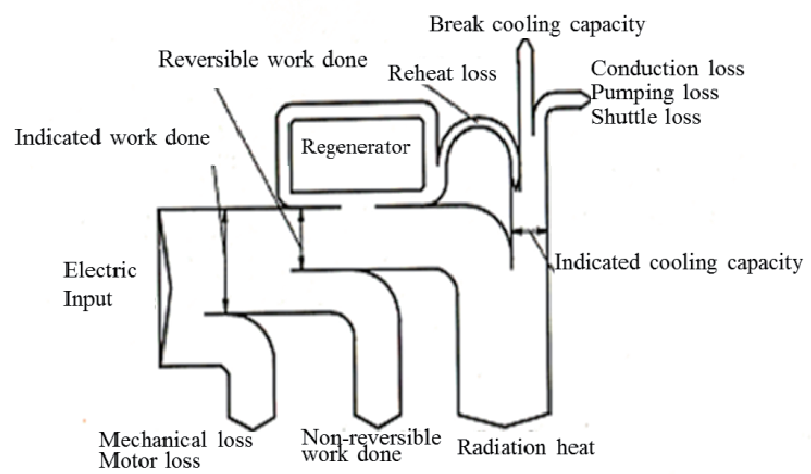

Fig. 11 Heat balance in a Stirling cryocooler.
熱伝導損失, シャトル損失，ポンピング損失などが含まれ る。一方， $\sum W_{\mathrm{o}}$ には連結境界部での圧力損失，ピストン シールからの漏れ損失, 等温過程とポリトロープ過程の違 いによる損失などが挙げられる。

蓄冷器の設計には, 式(25)の利用により $C O P_{\mathrm{i}}$ 值が最高 となる形状寸法（直径, 長さ）を有する最適設計が可能に なる。

\section{6. まとめ}

再生式熱交換器について，その役割を述べるとともに， 蓄冷器の設計に際して考慮しなければならない項目を示し た。また，マトリックス材の一つとして積層金網を取り上 げ, その素線内の蓄熱効果, マトリックスの蓄熱容量と伝 熱性能の評価, 並びに流動損失の評価法を紹介し, あわせ て，スターリング冷凍機用蓄冷器を一例とした伝熱性能及 び流動損失の総合評価法を述べ, 蓄冷器設計の流れを紹介 した。

\section{参 考 文 献}

1) 濱口和洋, 古川育聖, 山下 螈 : 「再生器の均一流れに及ぼ 寸出入口形状の影響」, 機論(B) 72-714 (2006) 491-497

2) 山下 㦑, 浜口和洋：「再生器マトリックス中の圧力損失お よび流速分布に及ぼす出入口面積の影響」, 機論(B) 64-624 (1998) 2702-2709

3) 奥山 昂, 平塚善勝, 濱口和洋 : 「小型パルス管冷凍機の蓄 冷器出入口形状が冷凍性能に及ぼす影響」, 機論(B) 78-794 (2012) 128-139

4) 濱口和洋, 真柄洋平, 山下 螈: 「金網積層体の圧力損失及 び伝熱特性に及ぼす積層方法の影響」, 機論(B) 70-697 (2004) 2425- 2432

5) M. Tanaka, et al.: "Flow and heat transfer characteristics of Stirling engine regenerator in oscillating flow", JSME Int. J., Ser. 2, 33 (1990) 283

6) 山下 厳, 濱口和洋, 香川 澄, 平田宏一, 百瀬 豊: 「ス ターリングエンジンの設計」，パワー社，東京 (2009) 124-129

7) 山下 餀ら：「スターリングエンジン及びその要素技術に関 する基礎的研究」, 機械技術研究所報告 No.145 (1988) 76

8) 浜口和洋, 高橋真太郎, 宮部英也：「再生器マトリックスの 伝熱性能（金網積層の場合）」，機論(B) 49-445 (1983) 20012010

9) H. Miyabe, S. Takahashi and K. Hamaguchi: "An approach to the design of Stirling engine regenerator matrix using packs of wire gauzes”, Proc. 17th IECEC (1982) 1839-1844

10）野間口 有：「超小形スターリングサイクル冷凍機について一 赤外線素子冷却用一」，冷凍 62-719 (1987) 1-7

濱 口 和 洋 1950 年 2 月 28 日生。1981 年明治大学大学 院工学研究科機械工学専攻博士課程単位取得満期退学。現在, 明 星大学理工学部総合理工学科機械工学系教授。主にスターリング エンジン, 熱音響エンジンの実験研究に従事。低温工学・超電導 学会, 日本機械学会, 日本設計工学会会員。工学博士。 